\title{
Relation of Chelated Iron (EDDHA-Fe) Applications with Iron Accumulation and Some Plant Nutrient Elements in Basil (Ocimum basilicum L.)
}

\author{
Sevinç Adiloğlu* \\ Tekirdağ Namık Kemal University, Faculty of Agriculture, Department of Soil Science and Plant Nutrition, \\ Süleymanpaşa,Tekirdă̆, Turkey
}

Received: 25 June 2020

Accepted: 21 October 2020

\begin{abstract}
In this study, the capability of the basil (Ocimum basilicum L.) plant as hyper accumulator in remediation of polluted soils was investigated. The study was carried out as pot trials under controlled conditions. Increasing concentrations of EDDHA-Fe $\left(0 \mathrm{mgkg}^{-1}, 25 \mathrm{mgkg}^{-1}, 50 \mathrm{mgkg}^{-1}, 150 \mathrm{mgkg}^{-1}\right.$, $\left.250 \mathrm{mgkg}^{-1}\right)$ were applied. The basil seedlings germinated in viols were acclimated into pots in triplicates and harvested 2 months later. The agro-morphological traits, Fe accumulation in plants and plant nutritional elements were analysed. The basil plant was found to accumulate Fe in its body in the presence of toxic levels of Fe metal and Fe was found to be antagonistic with micro nutritional elements. The plant fresh and dry weights and plant height were found to be statistically significant at $50 \mathrm{mgkg}^{-1}$ EDDHA-Fe application, and beyond this concentration, these values decreased. The $\mathrm{Mg}$ content, which is the central atom in chlorophyll, was found to be the highest at the mentioned concentration. SPAD values showed a parallel change, too. The basil plant was shown to be a hyperaccumulator in terms of remediation of the Fe metal, which is both a nutritional element and a heavy metal. Moreover, Fe fertilization of $50 \mathrm{mgkg}^{-1}$ was shown to be sufficient for basil cultivation as a medicinal plant. This result was found to be statistically significant at $\alpha=0.05$.
\end{abstract}

Keywords: accumulation, iron, basil, plant nutrient elements, hyper accumulator

\section{Introduction}

The increasing population and developing technology bring about the need for cultivation of

*e-mail: sadiloglu@hotmail.com

healthy products and use of these products in health area in today's world. The medicinal plants among these cultivated products are taking attention. Different parts of these plants (root, stem, leaf, and flower) are subject of different researches. The subject of the present study, the basil plant (Ocimum basilicum L.), is used as spice in nutrition, and also evaluated as raw material for pharmaceuticals. The soil pollution is increasing day 
by day due to many human and agricultural activities (industry, traffic, fertilizers, pests, etc.). The cohesion of soil, air, water and living organisms that form the ecosystems is vital for the healthy functioning of metabolisms. There are many chemicals in natural and artificial ecosystems that harm human metabolism and health. The chemicals possess a threat to organisms as a result of the breakdown of the environment. The pollution in any of the environments can be carried to another and therefore can be harmful. The importance of economically crucial agricultural soils is increasing by the increasing world's population. The agricultural soils are reducing due to many factors such as misuse, pollution, erosion, urbanization, industrialisation, highways and airports, etc. The fact that agricultural soils cannot be enlarged and replaced should never be forgotten when the soil pollution is investigated. Moreover, it should be kept in mind that polluted soil cannot be cleaned practically and nothing can be done but to leave the area. Therefore, the range of hyper accumulator plants should be expanded. Basil, one of the medicinal aromatic plants and an important cultivation [1-2].

The medicinal aromatic plant basil (Ocimum basilicum L.) is a rich source of minerals and Vitamin A. Only a few basil leaves of $2.5 \mathrm{~g}$ weight contain, $11.55 \mathrm{mg}$ potassium, $3.85 \mathrm{mg}$ calcium, 96.6 IU vitamin $A$ and a trace of vitamin, fibber, protein, minerals and less than 1 calorie [3-4]. The characteristic smell of basil is a result of the essential oil of the green leaves which is rich in aldehydes, terpene, and phenols. The phytochemical analysis of basil (Ocimum basilicum L.) revealed the presence of glycoside, gums, mucilage, proteins, amino acids, tannin, phenolic compounds, triterpenoid steroid, sterol, saponine, flavone and flavonoids [5]. The percentages of different compounds are as follows: oil 18-26\%, triglycerides $94-98 \%$, palmitic acid $6.1-11.0 \%$, oleic acid $8.5-13.3 \%$, linoleic acid 17.8-31.3\% and linolenic acid 43.8-64.8\% [3-4]. Basil is categorised as rich in (i) linalool; (ii) methyl chavicol; (iii) both linalool and methyl chavicol; (iv) both linalool and eugenol and (v) both methyl chavicol and methyl eugenol, depending on the compounds in essential oil [6].The oil obtained from the seed is mostly composed of oil and named as fixed oil [4]. There are many researches about the antibacterial, antioxidant, fungi static and insecticide properties of the essential oil obtained from [7-9]. Basil is commonly used because of its antioxidant, anti-inflammatory, anti-carcinogenic, antimicrobial and cardiovascular agent properties. At the same time, it can be used for cough and asthma, and abdominal pain resulted from colic. Basil is used as medicinal plant and also in biological plant protection because of the antibacterial and antifungal activities of its essential oil (Wetzel et al. 2008). Basil essential oil is also used in food and cosmetic industry; therefore, it is a multipurpose medicinal plant [4]. The plant itself is also used in preparation of various cold and hot meals as fresh or dried, and especially preferred in Italian cuisine for pesto sauce [7-9].

Metals are essential for all aerobic and anaerobic organisms. However, metals such as iron, chromium, lead, cobalt and cadmium threaten human health seriously when in high amount. Human body cannot process or excrete heavy metals; hence they accumulate in various organs. Accumulations of elevated amounts can seriously damage the human body. The most common environmentally polluting metals are cadmium, nickel, mercury, chromium, cobalt, silver, iron, copper, zinc, tin and lead [10].

Conventional agricultural practices increase day by day in order to obtain higher yields and feed the increasing world's population. Therefore, soils get polluted by excessive use of fertilizers and pesticides. Moreover, ever developing technical and industrial activities result also in organic and inorganic polluters that contaminates agricultural soils. Heavy metal contamination due to traffic is another reason for pollution. There is a need for cheap and efficient biological solutions for remediation of especially agricultural soils that are polluted by many ways. Phytoremediation is the leading biological solution. Using chelators increase the efficiency of this method [11]. The potential of use of basil for soil remediation, its response to iron toxicity and proper dose of iron fertilization were investigated in this study.

\section{Materials and Methods}

The experiment was carried out in Tekirdağ Namık Kemal University Faculty of Agriculture, Department of Soil Science and Plant Nutrition Laboratory in triplicates according to Randomized Complete Blocks Design. The EDDHA-Fe (GENTAFER Plus, GENTA, Turkey) was applied as $0 \mathrm{mg} \mathrm{kg}^{-1}, 25 \mathrm{mg} \mathrm{kg}^{-1}$, $50 \mathrm{mg} \mathrm{kg}$, $150 \mathrm{mg} \mathrm{kg}$, $250 \mathrm{mg} \mathrm{kg}^{-1}$ in triplicates. The plant material in this study was the medicinal aromatic plant basil (Ocimum basilicum L.). After the germination in viols, the seedlings were acclimated to the pots. Potassium sulphate fertilizer as potassium source, ammonium nitrate fertilizer as nitrogen source and triple superphosphate fertilizer as phosphorus source were applied to the pots during the planting to the pots (Fig. 1). The plants were harvested after 2 months of growth and agro morphological traits of each plant were measured [2]. After the measurements, the basil plants were washed with distilled water and the plant dry weights were determined after drying at $68^{\circ} \mathrm{C}$ for 48 hours [12]. Later, the elemental analyses were carried out with ICP-OES (Inductively Couple Plasma Spectrophotometer, Spectro Blue, Spectro, Germany) after extraction with microwave. The acid digestion of the dried plant materials was carried out with microwave burning unit (Mars 6, CEM, USA). The metal concentrations in the samples were determined with ICP-OES (Spectro Blue, Spectro, Germany) 
which is based on the atomisation of metals in plasma and measurement of plasma light emission. Plasma is formed by passing the argon gas in a radio frequency ring and the temperature of the plasma is $6000-8000 \mathrm{~K}$. The samples are aerosolised in nebulizer and given to the plasma. The samples of $0.5 \mathrm{~g}$ are burned with $10 \mathrm{ml}$ nitric acid and heat in microwave unit prior to injection to ICP-EOS.Teflon microwave tubes are used during this process. A calibration curve is prepared with the metal standards of interest [13].

\section{Some Physical and Chemical Analyses of the Experimental Soil}

Soil samples were air dried and sifted with $2 \mathrm{~mm}$ sieve. $\mathrm{pH}$ and the electrical conductivity of the soil sample were determined from 1/2.5 soil/water mixture [14-15], $\mathrm{CaCO}_{3}$ content was determined with Scheibler calcimeter [15], the texture was determined with Bouyoucos Hydrometer method [16], the organic matter content was determined according to modified Walkey-Black method [17]. Available phosphorus was analysed according to Olsen method [18], exchangeable $\mathrm{K}$ analysis was done according $1 \mathrm{~N}$ ammonium acetate (pH 7) method [17], and extractable $\mathrm{Fe}, \mathrm{Zn}, \mathrm{Cu}$ and $\mathrm{Mn}$ analyses were carried out according to DTPA method [19], The chlorophyll content analysis was carried out with mobile chlorophyll meter (Minolta SPAD-502, Osaka, Japan) which indirectly measure the chlorophyll content of the leaves.

The statistical analyses of the results were carried out in SPSS according to the randomized block design. The significance of the differences between the trials were controlled with Duncan test.

\section{Results and Discussion}

Some chemical and physical properties of the research soil are given in Table 1 .

The soil was slightly acidic in terms of the $\mathrm{pH}$ value, insufficient in organic matter, and non-saline (Table 1).
Table 1. Data of the experiment soil

\begin{tabular}{|c|c|c|}
\hline Soil properties & Unit & Value \\
\hline $\mathrm{pH}$ & $(1: 2.5$ soil: water $)$ & 6.44 \\
\hline Electrical Conductivity & $\%$ & 0.14 \\
\hline $\mathrm{CaCO}_{3}$ & $\%$ & 9.15 \\
\hline Organic matter & $\%$ & 1.91 \\
\hline Available $\mathrm{P}_{2} \mathrm{O}_{5}$ & $\mathrm{mgkg}^{-1}$ & 35.37 \\
\hline Exchangeable $\mathrm{K}_{2} \mathrm{O}$ & $\mathrm{mgkg}^{-1}$ & 225.18 \\
\hline Available $\mathrm{Fe}$ & $\mathrm{mgkg}^{-1}$ & 0.18 \\
\hline Available $\mathrm{Cu}$ & $\mathrm{mgkg}^{-1}$ & 0.75 \\
\hline Available $\mathrm{Zn}$ & $\mathrm{mgkg}^{-1}$ & 0.63 \\
\hline Available $\mathrm{Mn}$ & $\mathrm{mgkg}^{-1}$ & 1.47 \\
\hline Clay & $\%$ & 16 \\
\hline Silt & $\%$ & 31 \\
\hline Sand & - & 53 \\
\hline Texture class & & $\mathrm{SL}$ \\
\hline
\end{tabular}

The other parameters of the soil are sufficient except iron. The insufficiency of iron in the trial soil will allow us to see the response of the plant to our applications. The soil was loamy in terms of texture, which is desired texture in terms of agricultural activities and water and air balance in the soil.

When the results are evaluated in terms of agro morphological traits, the wet weight of the plants decreased with the applications over $50 \mathrm{mg} \mathrm{kg}^{-1}$. Similar to this, dry weights of the plants decreased with doses over $50 \mathrm{mg} \mathrm{kg}^{-1}$ (Table 2). Similar results were observed for plant length and leaf number in plant. The SPAD results increased up to $50 \mathrm{mg} \mathrm{kg}^{-1}$ and decreased over this dose. The mentioned increases were statistically significant at $5 \%$ level. The effects of Fe applications on some agro morphological traits were shown in Fig. 2.

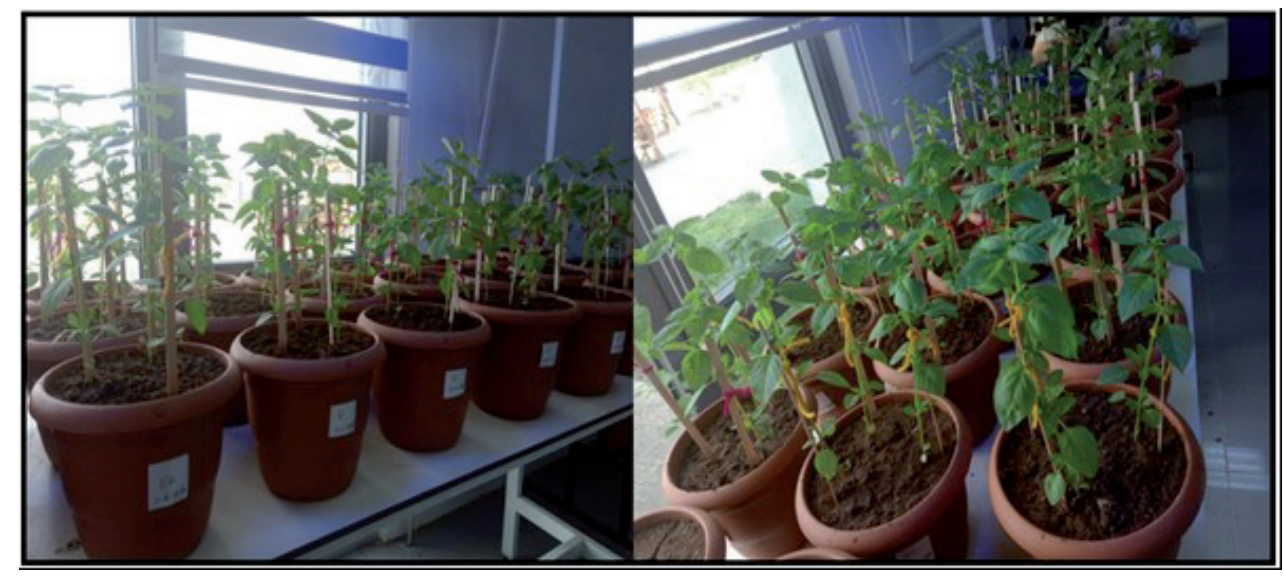

Fig. 1. Photos from experimental process (original). 
Table 2. Some agro-morphological measurements* of basil (Ocimum basilicum L.).

\begin{tabular}{|c|c|c|c|c|c|}
\hline Doses (Fe) & Fresh weight (gr) & Dry weight (gr) & Plant height (cm) & Leaf number & SPAD \\
\hline Control & $26.37 \pm 2.6 \mathrm{ab}$ & $2.74 \pm 0.2 \mathrm{ab}$ & $48.33 \pm 0.7 \mathrm{a}$ & $39.33 \pm 6.4 \mathrm{~ns}$ & 7.42 \\
\hline $25 \mathrm{mgkg}^{-1}$ & $31.55 \pm 4.3 \mathrm{a}$ & $3.80 \pm 0.6 \mathrm{a}$ & $50.14 \pm 3.2 \mathrm{a}$ & $37.33 \pm 1.7 \mathrm{~ns}$ & 9.70 \\
\hline $50 \mathrm{mgkg}^{-1}$ & $25.17 \pm 3.0 \mathrm{ab}$ & $2.71 \pm 0.2 \mathrm{ab}$ & $42.66 \pm 5.2 \mathrm{a}$ & $33.33 \pm 7.4 \mathrm{~ns}$ & 22.53 \\
\hline $150 \mathrm{mgkg}^{-1}$ & $18.60 \pm 2.5 \mathrm{~b}$ & $2.03 \pm 0.6 \mathrm{c}$ & $38.26 \pm 2.9 \mathrm{ab}$ & $31.66 \pm 2.02 \mathrm{~ns}$ & 20.23 \\
\hline $250 \mathrm{mgkg}^{-1}$ & $8.24 \pm 1.6 \mathrm{c}$ & $1.02 \pm 0.2 \mathrm{c}$ & $29.44 \pm 7.7 \mathrm{~b}$ & $27.66 \pm 3.8 \mathrm{~ns}$ & 15.69 \\
\hline
\end{tabular}

*: values are the mean of three replicates

Application of increasing doses of fertilizers (750, 1000, 1250, $1500 \mathrm{~kg} \mathrm{da}^{-1}$ ) on basil (Ocimum basilicum L.) revealed a significant correlation with plant wet and dry weight, and plant length in the study by Yaldiz et al. [20]. The differences between branch numbers were not significant. This study showed the positive effect of organic fertilizer use on biological traits of the plant. Organic fertilizers are rich in micro elements [21].

Yaldiz et al., [22], found the wet herb yield as $1869.3-6184.2 \mathrm{~kg} \mathrm{da}^{-1}$ in their study with green and purple basil. They also found the dry herb yield as 284.8 - $865.8 \mathrm{~kg} \mathrm{da}^{-1}$ in their study in ecological conditions of Rize-Pazar. In a study with three different basil species (O. basilicum, $O$. sanctum and $O$. citriodorum), El-Sayed et al., [23] stated that application of $100 \mathrm{~g}$ poultry manure and $125 \mathrm{ppm}$ humic acid increased the plant wet weight, in their study to investigate the effects of 100 and 200 g poultry manure and 125 and $150 \mathrm{ppm}$ humic acid applications on herb yield and essential oil yield of three basil species. They also found that $100 \mathrm{~g}$ poultry manure and $125 \mathrm{ppm}$ humic acid increased the plant length, too.

The lowest chlorophyll amount was in the control pot (Fig. 2). This was because of the insufficiency of Fe in the trial soil (Table 1). Fe is not included in the chlorophyll structure, but participate in the ferredoxin
$\mathrm{NADP}^{+}$which transport electrons to nitrate reductase, $\mathrm{N}_{2}$ reductase and sulphite reductase enzymes and therefore plays a role in photosynthesis. Ferredoxin and chlorophyll contents of the leaves change upon the Fe contents [24] (The SPAD values increase with the increasing EDDHA-Fe applications. However, with the application of $150 \mathrm{mg} \mathrm{kg}^{-1}$ dose the content of $\mathrm{Fe}$ in the basil (Ocimum basilicum L.) became toxic in the plant and this caused a decrease in chlorophyll contents, but they were still higher than the control condition. This situation shows the accumulation of $\mathrm{Fe}$ in the plant body.

The effects of increasing doses of Fe applications on some macro nutrient elements of basil were given in Table 3. The N\% content of the plant increased with increasing $\mathrm{Fe}$ applications. The $\mathrm{P}, \mathrm{Ca}$ and $\mathrm{Mg}$ contents of the basil increased with increasing $\mathrm{Fe}$ applications up to $50 \mathrm{mg} \mathrm{kg}^{-1}$, then started to decrease. The $\mathrm{K}$ content of the plant increased up to $150 \mathrm{mg} \mathrm{kg}^{-1}$, and decreased over this dose. These results were statistically significant at 5\% and they can be seen in Fig. 3 .

In a study with four different basil varieties (Ocimum basilicum 'Italian Large Leaf, O. basilicum' Mobarakeh, O. basilicum' Cinnamon' and O. basilicum' Thai'), three different doses of nitrogen fertilizer urea $(0,100$ ve $200 \mathrm{~kg} \mathrm{ha}^{-1}$ ) were applied. The highest dry weight (3482.4 $\mathrm{kg} \mathrm{ha}^{-1}$ ) was obtained at Ocimum basilicum [25].

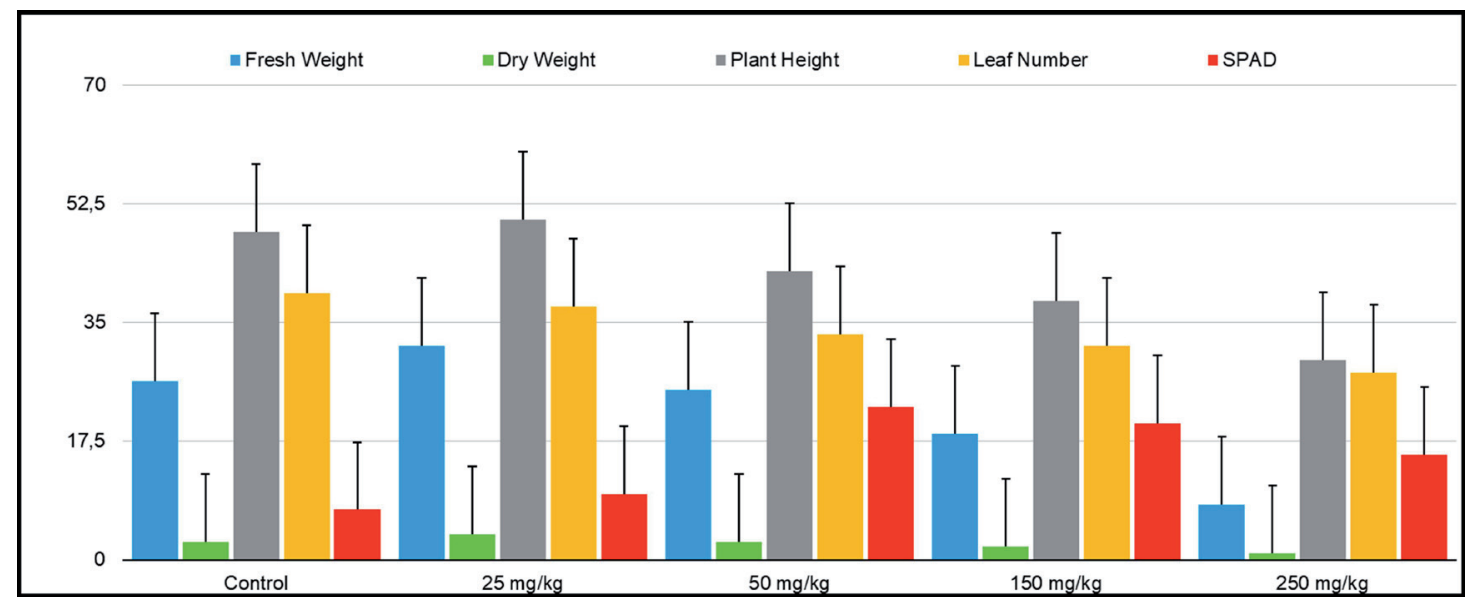

Fig. 2. Effects of EDDHA-Fe applications on some agro-morphological traits of basil (Ocimum basilicum L.) 
Table 3. The relationship of iron toxicity with some macro nutrient elements of basil (Ocimum basilicum L. $)^{+}: \%,{ }^{*}, \mathrm{mgkg}^{-1}$,

\begin{tabular}{|c|c|c|c|c|c|}
\hline Doses $(\mathrm{Fe})$ & $\mathrm{N}^{+}$ & $\mathrm{P}$ & $\mathrm{K}$ & $\mathrm{Ca}$ & $\mathrm{Mg}$ \\
\hline Control & $2.81 \pm 0.01 \mathrm{e}$ & $425 \pm 16.6 \mathrm{~b}$ & $3057 \pm 46.4 \mathrm{e}$ & $4202 \pm 21.9 \mathrm{a}$ & $731 \pm 61.0 \mathrm{~b}$ \\
\hline $25 \mathrm{mgkg}^{-1}$ & $2.92 \pm 0.02 \mathrm{~d}$ & $415 \pm 18.1 \mathrm{~b}$ & $3346 \pm 27.7 \mathrm{~d}$ & $3143 \pm 29.5 \mathrm{ab}$ & $744 \pm 71.5 \mathrm{~b}$ \\
\hline $50 \mathrm{mgkg}^{-1}$ & $3.21 \pm 0.01 \mathrm{c}$ & $456 \pm 29.0 \mathrm{a}$ & $3996 \pm 29.5 \mathrm{~b}$ & $3107 \pm 14.4 \mathrm{~b}$ & $807 \pm 43.7 \mathrm{a}$ \\
\hline $150 \mathrm{mgkg}^{-1}$ & $3.38 \pm 0.08 \mathrm{~b}$ & $335 \pm 29.3 \mathrm{c}$ & $4232 \pm 48.4 \mathrm{a}$ & $2339 \pm 22.3 \mathrm{c}$ & $572 \pm 20.28 \mathrm{c}$ \\
\hline $250 \mathrm{mgkg}^{-1}$ & $3.68 \pm 0.05 \mathrm{a}$ & $323 \pm 28.5 \mathrm{~d}$ & $3721 \pm 68.6 \mathrm{c}$ & $2233 \pm 18.2 \mathrm{~d}$ & $481 \pm 49.5 \mathrm{~d}$ \\
\hline
\end{tabular}

*: values are the mean of three replicates

The nutritional contents of two basil species Ocimum grattissimum and Ocimum basilicum were investigated in another study. The potassium $(462-483 \mathrm{mg} / 100 \mathrm{~g})$, calcium (540-460 $\mathrm{mg} / 100 \mathrm{~g})$, phosphorus (26.9-35.9 $\mathrm{mg} / 100 \mathrm{~g}$ ), iron (11.4-10.5 mg/100 g) were obtained as mentioned in the parentheses. These results were similar to those of the control condition and positively affected the elimination of Fe deficiency and also
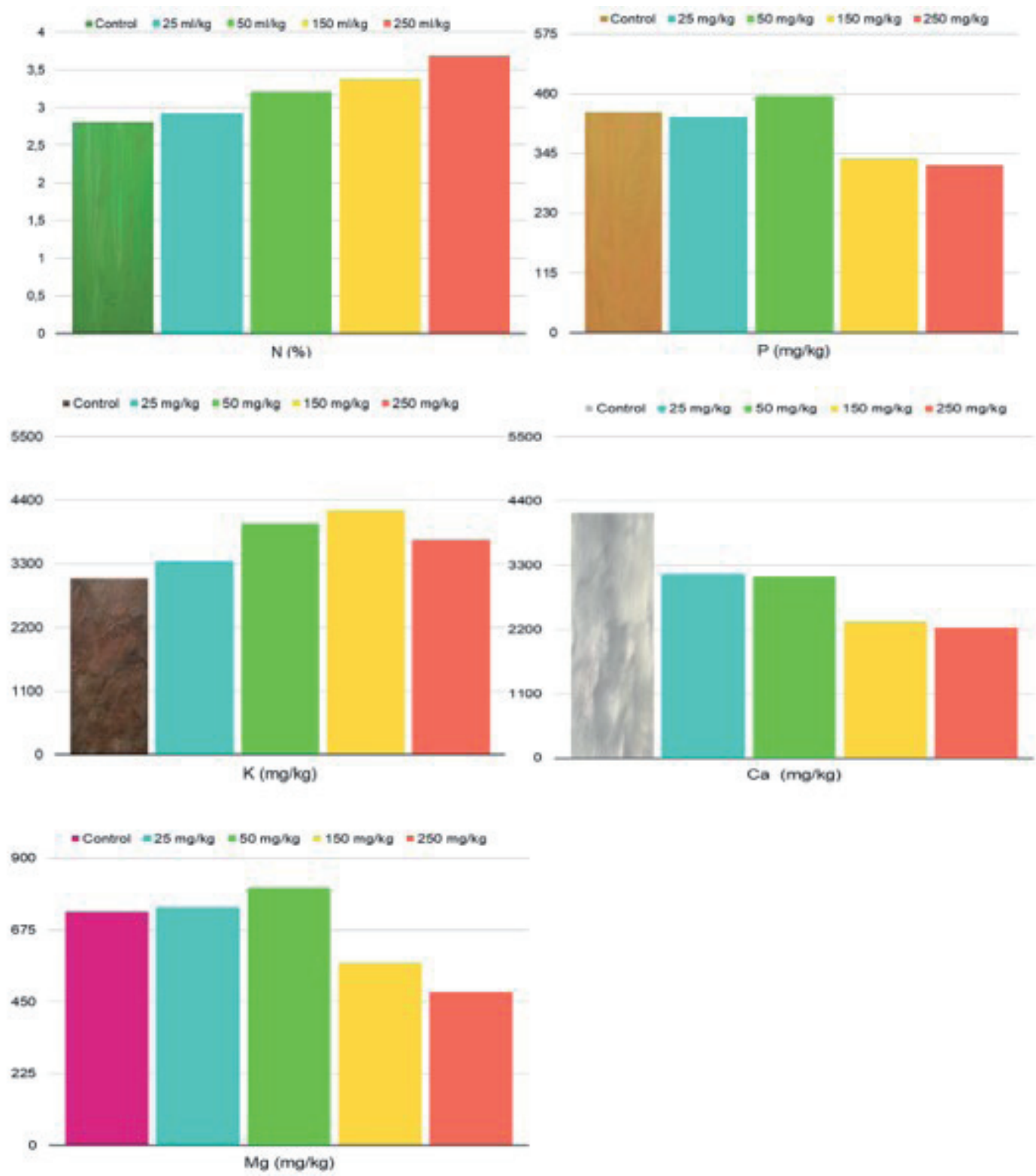

Fig. 3. The effects of EDDHA-Fe applications on macro nutrient elements. 
Table 4. The relationship of Fe toxicity with some micro nutrient elements of the basil (Ocimum basilicum L.), *, $\mathrm{mgkg}^{-1}$.

\begin{tabular}{|c|c|c|c|c|}
\hline Doses $(\mathrm{Fe})$ & $\mathrm{Cu}$ & $\mathrm{Zn}$ & $\mathrm{Mn}$ & $\mathrm{Fe}$ \\
\hline Control & $9.65 \pm 0.11 \mathrm{c}$ & $43.05 \pm 0.11 \mathrm{e}$ & $231 \pm 2.70 \mathrm{a}$ & $139 \pm 0.27 \mathrm{e}$ \\
\hline $25 \mathrm{mgkg}^{-1}$ & $16.58 \pm 0.10 \mathrm{~b}$ & $45.3 \pm 0.81 \mathrm{~d}$ & $143 \pm 0.33 \mathrm{~b}$ & $213 \pm 0.97 \mathrm{~d}$ \\
\hline $50 \mathrm{mgkg}^{-1}$ & $17.88 \pm 0.10 \mathrm{a}$ & $53.38 \pm 0.80 \mathrm{a}$ & $141 \pm 0.57 \mathrm{~b}$ & $255 \pm 1.50 \mathrm{c}$ \\
\hline $150 \mathrm{mgkg}^{-1}$ & $8.73 \pm 0.40 \mathrm{~d}$ & $49.33 \pm 0.30 \mathrm{~b}$ & $124 \pm 1.50 \mathrm{c}$ & $350 \pm 3.40 \mathrm{~b}$ \\
\hline $250 \mathrm{mgkg}^{-1}$ & $7.56 \pm 0.80 \mathrm{e}$ & $46.41 \pm 0.11 \mathrm{c}$ & $102 \pm 1.90 \mathrm{~d}$ & $384 \pm 8.70 \mathrm{a}$ \\
\hline
\end{tabular}

*: values are the mean of three replicates

the macro plant nutritional elements. However, when Fe reached toxic levels, it especially caused a significant change in P macro element [26].

Tavallalia et al. [27] investigated the essential oil, antioxidant and antimicrobial effects of the basil (Ocimum basilicum L.) upon applications of different $\mathrm{Fe}$ sources (Fe-arginine, Fe-glycine and Fe-histidinenano complexes, and Fe-EDDHA). The highest and lowest activities were recorded in Fe with application of Fe-histidine. As a result, the nanocomplexes of $\mathrm{Fe}$ significantly changed the biological and pharmacological properties of the basil essential oils. Moreover, they were shown to strongly affect the antioxidant and antimicrobial activities of the essential oils. In this situation, the toxic level metal accumulation is thought to strengthen the plant.

Another study with basil (Ocimum basilicum L.) was conducted to investigate the effects of (Feurea) nano-complexes phytochemical compounds on antioxidant and antimicrobial activities of the essential oil. Three different levels $(0,0.1$ and $0.2 \%)$ of Fe-EDDHA, urea and Fe-urea nano-complex were
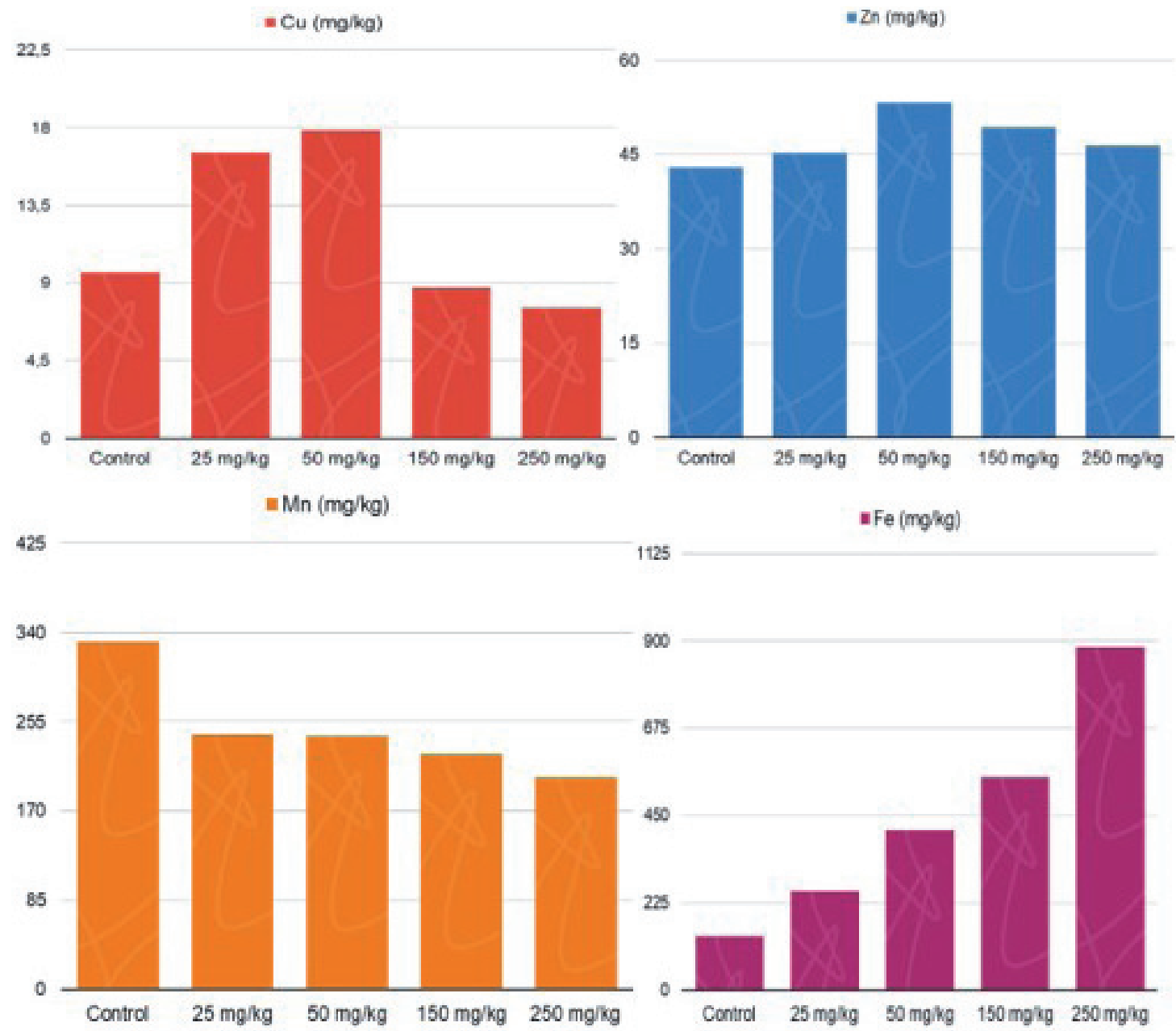

Fig. 4. The relationship of EDDHA-Fe applications with some micro nutrient elements. 
sprayed on the plant at the four-leaf period. The highest amounts of the main compounds in the essential oil were epi- $\alpha$-cadinol $(27.09 \% \pm 2.5 \%)$ and trans$\alpha$-bergamoten $(14.93 \% \pm 1.77 \%)$, were obtained with $0.2 \% \mathrm{n}$ (Fe-urea) application. The results show that the chelated $\mathrm{Fe}$ fertilization strengthen the biochemical properties of the plant [28]. Many biochemical factors and plant nutritional elements are interacted in metal accumulation of metals in chelated Fe fertilization.

Anwar et al. [29]. used both organic and inorganic fertilizers in six combinations in a field study. The effects of organic fertilizer (farm manure and vermicompost) and inorganic fertilizer (nitrogenphosphorus-potassium) on the yield and oil quality of Ocimum basilicum L. were investigated. When six trials of the experiment were compared, the highest yield in terms of plant wet and dry weights was obtained with vermicompost + NPK fertilization. Since there is a synergistic effect of $\mathrm{N}$ on $\mathrm{Fe}$ micro elements, when the plants were fed with enough $\mathrm{N}$, both agromorphological and nutritional elements contents were positively affected $[21,30]$.

Increasing doses of EDDHA-Fe applications increased the Fe contents in basil (Table 4). However, there is a decrease in agro-morphological traits especially after $50 \mathrm{mg} \mathrm{kg}^{-1}$ (Table 2). This decrease is parallel to the decrease in the contents of $\mathrm{Zn}, \mathrm{Mn}$ and $\mathrm{Cu}$ which are both heavy metal and nutrient elements. However, Fe accumulation in plant increased with EDDHA-Fe (250 $\left.\mathrm{mg} \mathrm{kg}^{-1}\right)$ application. The increased of Fe metal in plant showed an antagonistic effect and decreased the $\mathrm{Zn}, \mathrm{Mn}$ and $\mathrm{Cu}$ contents of the plant. These results were significant at 5\%. These results can be seen in Fig. 4.

The results were consistent with the study of Dinu et al. [31] who investigated the relation between some heavy metals with micro nutritional elements of the basil plant.

Kladsomboon et al. [32] evaluated the heavy metals (As, $\mathrm{Cd}, \mathrm{Cu}, \mathrm{Hg}, \mathrm{Pb}$ and $\mathrm{Zn}$ ) in a study conducted in Thailand. The contents of the heavy metals were in allowed limits in all plants (eggplant, cabbage and rice). Besides, both $\mathrm{Hg}$ and $\mathrm{Cu}$ were over the allowed levels in basil. The levels of heavy metals were in allowed limits in plants except basil, but increased compared to the previous levels. This situation is reported to possess an agricultural and environmental risk

Abbasifar et al. [33] used basil in $\mathrm{Zn}$ and $\mathrm{Cu}$ nano particle leaf fertilization and investigated the effects of high concentrations of $\mathrm{Zn}$ and $\mathrm{Cu}$ on agromorphological traits, chlorophyll and carotene contents, phenolic and flavonoid contents and antioxidant contents. This application showed significant effects and quality parameters of the plant increased.

The present study revealed the capability of the Ocimum basilicum plant to accumulate heavy metals, especially those with plant nutrient element role. Szczodrowska et al., [34] investigated the accumulation of $\mathrm{Ni}, \mathrm{Zn}$ and $\mathrm{Cu}$ applied to the soil by Lepidium sativum, Ocimum basilicum and Mentha piperita, which belong to Brassicaceae and Lamiaceae families. When the effects of metal ions on factors such as growth and morphology were examined, they showed to significantly increase the metal ion concentration in the plants. Application of $\mathrm{Zn}$ ions significantly increased the uptake of $\mathrm{Zn}$ by Ocimum basilicum and Mentha piperita (Lamiaceae family). $\mathrm{Ni}$ ions significantly increased the accumulation of $\mathrm{Ni}$ in Lepidium sativum (Brassiaceae family). The study showed that $\mathrm{Ni}, \mathrm{Zn}$ and $\mathrm{Cu}$ were accumulated in different concentrations in leaves depending on the plant species.

Some heavy metals (Fe, $\mathrm{Mn}, \mathrm{Cu}$, and $\mathrm{Zn}$ ) are also essential micro nutrient elements that have important roles in plant growth and development. The dynamic balance of these heavy metals, their toxicity and insufficiency contents are especially important for the cells. Remediation of Cd with Salix matsudana plant was investigated in a study by $\mathrm{Wu}$ et al. [35]. Stress upon $50 \mu \mathrm{M}$ Cd resulted in decrease in $\mathrm{Fe}(34.1 \%), \mathrm{Zn}$ (40.7), Mn (60.1\%) and Ca (26.5\%). However, the $\mathrm{Cd}$ tolerance gene of the plant provided accumulation due to complex physiological and biochemical processes such as coordination of the expression of secondary metabolites and protein modification. The active metabolic uptake of Fe by plants greatly affect the uptake of other metals [21].

The effects of some heavy metals on plant growth and heavy metal accumulation of Ocimum basilicum used in ecotoxicity studies were evaluated, and accumulation of some heavy metals $(\mathrm{Cd}, \mathrm{Co}, \mathrm{Cr}, \mathrm{Cu}, \mathrm{Ni}$, $\mathrm{Pb}$, and $\mathrm{Zn}$ ) and their translocation to plant organs of Ocimum basilicum L. grown in polluted and unpolluted soils were evaluated with transfer coefficient. Different metals were shown to be accumulated in organs $(\mathrm{Cd}$, $\mathrm{Co}, \mathrm{Cr}, \mathrm{Pb}$ ) and roots $(\mathrm{Cu}, \mathrm{Ni}, \mathrm{Zn})$. Especially $\mathrm{Cr}$ and $\mathrm{Pb}$ were in toxic levels in roots. The results of the experiments showed that the $\mathrm{Cd}$ and $\mathrm{Pb}$ contents of the basil plants exposed to negative effects of heavy metals, exceeded the legal levels, therefore the consumption of these plants was restricted [31]. This supports the result of this study that this plant can hyperaccumulate different heavy metals in different doses.

\section{Conclusions}

The medicinal and aromatic basil plant (Ocimum basilicum L.) belonging to the Lamiaceae family is an economically important plant. Basil is frequently consumed in cosmetics, traditional medicine, aromatherapy, and as food aroma thanks to the essential oil it possesses. The basil essential oil is thought to be responsible for its antimicrobial, insecticidal, nematicidal, fungistatic, herbicidal, and antioxidant properties, and for the plant to be resilient to stress factors. This study revealed the response of basil to the heavy metal stress which is one of the most significant pollution parameters in agricultural areas. 
The accumulation of the metal iron which is very essential for plants in plant body in areas with toxic levels of irons resulted from excess fertilization, agricultural spraying and other sources was investigated with this study. The correlation of phytotoxic capacity of basil with some essential micro and macro nutritional elements was evaluated. The phytotoxicity tests are usually based on methods used for EPA48 and OECD49 chemicals. The phytotoxicity tests are carried out in two parts of the plants: root elongation and change in dry weight during germination and plant growth [36].

When increasing amounts of Fe was applied on basil and some agro-physiological traits were examined, plant fresh and dry weights, plant height, leaf number and SPAD values were found to be increased at $50 \mathrm{mg} \mathrm{kg}^{-1}$ Fe application and decreased by further applications. It is clear that $\mathrm{Fe}$ applications more than the mentioned dose caused toxicity in basil. These values, except for plant height were found to be statistically significant at $5 \%$. The $\% \mathrm{~N}$ values, $\mathrm{P}$ and $\mathrm{Mg}$ contents of the plant were found to increase with up to $50 \mathrm{mg} \mathrm{kg}^{-1} \mathrm{Fe}$, and decrease by further doses of Fe. The K content increased with up to $150 \mathrm{mg} \mathrm{kg-}^{-1} \mathrm{Fe}$ and decreased with further doses. The $\mathrm{Ca}$ content was found to decrease with increasing $\mathrm{Fe}$ doses. These results were consistent with previous studies [37]. Similarly, the $\mathrm{Cu}$ and $\mathrm{Zn}$ contents increased with up to $50 \mathrm{mg} \mathrm{kg}^{-1} \mathrm{Fe}$ then decreased with higher $\mathrm{Fe}$ amounts. The $\mathrm{Mn}$ content decreased with increasing $\mathrm{Fe}$ doses. The Fe content of the plant increased with increasing Fe applications. The mentioned increases and decreases were statistically significant and compatible with previous studies [38]. This study showed that iron fertilization for basil (Ocimum basilicum L.) is necessary in soils poor in Fe. However, high $\mathrm{Fe}$ concentration in soil caused by fertilizations or other applications cause $\mathrm{Fe}$ accumulations in this plant. It can be stated that basil is a hyperaccumulator for $\mathrm{Fe}$ in cases of Fe toxicity and can be used in phytoremediation of Fe contaminated soils. This result is also important in terms of reducing fertilizer use for sustainable soil productivity and remediation of soil contamination.

\section{Conflict of Interest}

The authors declare no conflict of interest.

\section{References}

1. ADİLOĞLU S. An investigation of some heavy metal pollution along the TEM motorway soils in Tekirdağ. Namık Kemal University, Graduate School of Natural and Applied Sciences Main Science Division of Soil Science and Plant Nutrition. Tekirdağ, Turkey. 2013.

2. CABAR B.S. Determınation of Some Yield and Quality Components of Sweet Basil (Ocimum basilicum L.) Lines From Different Origins in Thrace Region. Namık Kemal
University, Graduate School of Natural and Applied Sciences, Department of Agronomy. Tekirdağ, Turkey. 2016.

3. HANIF M.A., AL-MASKARİ M.Y., AL-MASKARİ A., AL-SHUKAİLİ A., AL-MASKARİ A.Y., AL-SABAHİ J. $\mathrm{N}$. Essential oil composition, antimicrobial and antioxidant activities of unexplored Omani basil. Journal of Medicinal Plants Research, 5 (5), 751, 2011.

4. NADEEM F., HANIF M.A., BHATTİ I.A., JILANI M.I., AL-YAHYAİ R. Basil. Medicinal Plants of South Asia, 47. https://doi.org/10.1016/b978-0-08-102659-5.00004-5, 2020.

5. ALİA BÍLAL N. Phytochemical and Pharmacological Studies on Ocimum Basilicum Linn - a Review -. International Journal of Current Research and Review, 4 (23), 2012.

6. AKBARİ G.A., BİNESH S., RAMSHINI H., SOLTANİ E., AMINII F., MİRAZELI M.S. Selection of basil (Ocimum basilicum L.) full-sib families from diverse landraces. Journal of Applied Research on Medicinal and Aromatic Plants, 66-72. https://doi.org/10.1016/j. jarmap.2018.12.003, 2019.

7. MACHADO M.M., DE OLIVEIRA L.F.S., ZURAVSKİ L. Ocimum basilicum L.: Antiinflammatory Actions and Potential Usage for Arthritic Conditions. Bioactive Food as Dietary Interventions for Arthritis and Related Inflammatory Diseases ( $2^{\text {nd }}$ ed.). Elsevier Inc. https://doi. org/10.1016/b978-0-12-813820-5.00027-1, 2019.

8. MOSTAFAVİ S., ASADİ-GHARNEH H.A., MIRANSARİ M. The phytochemical variability of fatty acids in basil seeds (Ocimum basilicum L.) affected by genotype and geographical differences. Food Chemistry, 276, 700, 2019.

9. WETZEL S.B., KRÜGER H., HAMMER K., BACHMANN K. Investigations on Morphological, Biochemical and Molecular Variability of Ocimum L. Species. Journal of Herbs, Spices \& Medicinal Plants, 9 (2-3), 183, 2008.

10. FORSTER C.F., WASE DAJ. Biosorption of Heavy Metals: an Introduction. Biosorbents for Metal Ions Chapter 1. Editor: Taylor and Francis. London. 1997.

11. ADİLOĞLU S. Using Phytoremediation with Canola to Remove Cobalt from Agricultural Soils. Polish Journal of Environmental Studies, 25 (6), 2251, 2016.

12. KACAR B., İNAL A. Plant Analysis. Ankara: Nobel Publ. 2010.

13. EPA Method 3052. Microwave Assisted Acid Digestion of Siliceous and Organically Based Matrices. 1996.

14. JACKSON M.C. Soil chemical analysis. Prentice Hall of India Private' Limited, New Delhi. 1967.

15. SAĞLAM M.T. Chemical Analysis Methods of Soil and Water. Namık Kemal University. Publ 2, Tekirdağ. 2012.

16. BOUYOUCOS G.J. A Recalibration of the Hydrometer Method for Making Mechanical Analysis of the Soils. Agronomy Journal, 4 (9), 434, 1955.

17. KACAR B. Chemical analysis of Plant and Soil-III. Soil Analysis. A.U. Agric. Fac. Edication., Research and Development Society Publ. No: 3, Ankara 1995.

18. OLSEN S.R., SOMMERS L.E. Methods of soil analysis. Part II. Chemical and microbiological properties. Editors: Page, A.L., R.H. Miller, D.R. Keeney. Agronomy. No: 9 Madison, Wisconsin, USA. 1982.

19. LINDSAY W.L., NORVELL W.A. Development of a DTPA soil test for zinc, iron, manganase and copper. Soil Sci. Soc.Am.J., 42, 421, 1978.

20. YALDIZ G., ÇAMLICA M., ERATALAR A.S., KULAK M. The Effects of Different Kibele Fertilizer Applications 
on Yield of Sweet Basil (Ocimum basilicum L.) Iğdır Univ. J. Inst. Sci. \& Tech. 7 (1), 363, 2017.

21. KARAMAN M.R., ADILOĞLU A., BROHI R., GÜNEŞ A., İNAL A., KAPLAN M., KATKAT V., KORKMAZ A., OKUR N., ORTAŞ İ., SALTALI K., TABAN S., TURAN M., TÜFENKÇI Ş., ZENGIN M. Plant Nutrition. Ankara (Turkey). Dumat Offset. 2012.

22. YALDIZ G., GÜL F., KULAK M. Herb yield and chemical composition of basil (Ocimum basilicum L.) essential oil in relation to the different harvest period and cultivation conditions. African Journal of Traditional Complementary and Alternative Medicines, 12, 71, 2015.

23. EL-SAYED A.A., EL-HANAFY S.H., EL-ZİAT RA. Effect of chicken manure and humic acid on herb and essential oil production of Ocimum sp. American-Eurasian Journal of Agricultural and Environmental Sciences, 15, 367, 2015.

24. MARSCHNER H. Mineral Nutrition of Higher Plants. p. 1-889. eBook ISBN: 9780080571874 Academic Press. New York. 1995.

25. MOAYEDI F., KORDI S., MEHRABI A.A. Evaluation Of Yield, Chemical Composition And Yield Of Essential Oil of Four Cultivars of sweet basil (Ocimum basilicum L.) affected by different levels of nitrogen. Acta agriculturae Slovenica, 115 (1), 171, 2020.

26. SHUAİB O.R., ADENIRAN O.I., MUSAH M., YERIMMA H., SANİ H., AMUSAT, K. Comparative Nutritional And Anti-Nutritional Analysis of Ocimum grattissimum and Ocimum basilicum. Academ Arena, 7 (7), 77, 2015.

27. TAVALLALİA V., KİANIBB M., HOJATİA S. Iron nanocomplexes and iron chelate improve biological activities of sweet basil (Ocimum basilicum L.). Plant Physiology and Biochemistry, 144, 445, 2019.

28. TAVALLALİA V., ROWSHANB V., GHOLAMİC H., HOJATİA S. Iron-urea nano-complex improves bioactive compounds in essential oils of Ocimum basilicum L. Scientia Horticulturae, 265, 109222, 2020.

29. ANWAR M., PATRA D.D., CHAND S., ALPESH K, NAQVİ A. A., KHANUJA S.P.S., Effect of Organic Manures and Inorganic Fertilizer on Growth, Herb and Oil Yield, Nutrient Accumulation, and Oil Quality of French Basil. Communications in Soil Science and Plant Analysis, 36, 1737, 2007.
30. ADİLOĞLU A., ADİLOĞLU S. Fertilizer Consumption in Turkey Between 1960 and 2002., Bulgarian Journal of Agricultural Sciences, 317, 2005.

31. DİNU C., VASILLE G.G., BULEANDRA M., POPA D.E., GHEORGHE S., UNGUREANU E.M. Translocation and accumulation of heavy metals in Ocimum basilicum L. plants grown in a mining-contaminated soil. Journal of Soils and Sediments, 20, 2141, 2020.

32. KLADSOMBOON S., JAIYYEN C., CHOPRATHUMMA C., TUSAİ T., APILUX A. Heavy metals contamination in soil, surface water, crops, and resident blood in Uthai District, Phra Nakhon Si Ayutthaya, Thailand. Environ Geochem Health, 42, 545, 2020 .

33. ABBASİFAR A., SHAHRABADİ F., VALİZADEHKAJİ B. Effects of green synthesized zinc and copper nanofertilizers on the morphological and biochemical attributes of basil plant. Journal of Plant Nutrition, 43 (8), $1104,2020$.

34. SZCZODROWSKA A., KULBAT K., SMOLIŃSKA B., LESZCZYŃSKA J., Accumulation of metal ions in selected plants from Brassicaceae and Lamiaceae families. Biotechnol Food Sci, 80 (1), 29, 2016.

35. WU H., WANG J., Lİ B., OU Y., JIAANG W., LIUU D., ZOU J., Uptake and Accumulation of Cadmium and Relative Gene Expression in Roots of Cd-resistant Salix matsudana Koidz. Polish Journal of Environmental Studies, 25 (6), 2717, 2016.

36. ÇİFÇI D.İ., ADİLOĞLU S., TERZİ S., MERIÇ S. A Review on Aquatic and Phtotoxicity Effect of Cerium and Lithum From Rare Earth Elements. Ömer Halisdemir University Journal of Engineering Sciences, 8, 9, 2019.

37. GHADA F.H., EL-SHEREF., AWADALLA H.A., MOHAMED A. Influence of Organic Manure, Natural Rocks and Putrescine on Yield and Quality of Sweet Basil (Ocimum basilicum L.) Grown in Sand Soil. J. of Soil Sciences and Agricultural Engineering, Mansoura Univ., 10 (2), 747, 2019.

38. ADILOGLU S. Interaction of Some Heavy Metals with Copper Content in Dock Plant. KSU Journal of Agriculture and Nature, 23 (4), 1078, 2020. 